\title{
Parthenon East Metope XI: Herakles and the Gigantomachy
}

\author{
Katherine Schwab \\ Fairfield University, kaschwab@fairfield.edu
}

Follow this and additional works at: https://digitalcommons.fairfield.edu/visualandperformingartsfacultypubs

Originally appears in American Journal of Archaeology. Copyright 1996 Archaeological Institute of America.

\section{Peer Reviewed}

\section{Repository Citation}

Schwab, Katherine, "Parthenon East Metope XI: Herakles and the Gigantomachy" (1996). Visual \& Performing Arts Faculty Publications. 5.

https://digitalcommons.fairfield.edu/visualandperformingarts-facultypubs/5

\section{Published Citation}

Schwab, Katherine. 1996. "Parthenon East Metope XI: Herakles and the Gigantomachy." AJA 100(1):81-90.

This item has been accepted for inclusion in DigitalCommons@Fairfield by an authorized administrator of DigitalCommons@Fairfield. It is brought to you by DigitalCommons@Fairfield with permission from the rightsholder(s) and is protected by copyright and/or related rights. You are free to use this item in any way that is permitted by the copyright and related rights legislation that applies to your use. For other uses, you need to obtain permission from the rights-holder(s) directly, unless additional rights are indicated by a Creative Commons license in the record and/or on the work itself. For more information, please contact digitalcommons@fairfield.edu. 


\title{
Parthenon East Metope XI: Herakles and the Gigantomachy
}

\author{
KATHERINE A. SCHWAB
}

\begin{abstract}
Parthenon East Metope XI, one of two metopes with three figures in the composition, has been one of the most problematic in the east series. C. Praschniker, in his study of the east metopes in 1928, was the first to propose Herakles as the central figure. Subsequent scholars have challenged this identification, suggesting instead Apollo, Ares, or Hephaistos. A comparison with representations of the Gigantomachy on vases of the fifth century B.C. supports Herakles for the central fig. ure in East XI. An examination of plaster casts of the metope in Basel and in Athens provides evidence to reconstruct the figure equipped with a large bow in his outstretched left hand and the position of his right foot. The new evidence for the pose and attributes further supports the identification of the central figure as Herakles. Correlations to another three-figure composition in the east metopes, as well as placement on the facade and alignment with the ground plan of the temple, underscore the important role given to Herakles in this representation of the battle of the gods and giants.*
\end{abstract}

The first major study of the Parthenon east metopes, including the reconstruction of the compositions and the identification of the figures and their interpretation, was conducted by C. Praschniker in 1928..$^{1}$ A. Michaelis had already established the theme of the 14 east metopes as the battle of the gods and giants, after recognizing Dionysos accom. panied by a snake attacking a fleeing figure in East II. ${ }^{2}$ It is remarkable that any theme could be de.

\footnotetext{
* An earlier version of this paper was presented at the 94th Annual Meeting of the Archaeological Institute of America in New Orleans, December 1992 (AJA 97 [1993] 310 , abstract). Funding was provided by Fairfield University to support my research in Athens and Basel. In Athens I wish to thank the Ephor of the Acropolis, Peter Kalligas, for permission to study the plaster casts of the east metopes in the Center for the Acropolis at Athens. I also wish to thank Alexander Mantis, Curator of Antiquities of the Acropolis Museum, for his generous assistance in arrang. ing for me to study the casts, and for his comments and observations in numerous discussions concerning the casts of the east metopes. I thank Aileen Ajootian, Robert Bridges, Evelyn Harrison, Caroline Houser, and Christina Salowey for discussing my research at various stages and offering helpful observations, suggestions, and encouragement. I also thank Manolis Korres for discussing with me his discoveries in the composition of East Metope XIV. In Basel I wish to thank Ernst Berger and Margot Schmidt
}

American Journal of Archaeology 100 (1996) 81-90 tected, even though all of the metopes are extant, since their state of preservation is poor, having suffered considerable damage when the temple was converted to a church in the Early Christian era. ${ }^{3}$ The groups of figures in each composition, $1.21 \mathrm{~m}$ in height and carved in high relief, were chopped and gouged from the surface. This deliberate destruc. tion has left a complex and sometimes enigmatic surface with contour lines partially defining some of the figures.

Praschniker's thorough knowledge of published vases of the time, and his use of vase painting iconography for comparative purposes, enabled him to offer reconstruction drawings for each composition that have served as the fundamental images for the east metopes ever since. F. Brommer's systematic description, interpretation, and photographic documentation have become essential as the corrosive effects of air pollution have increasingly eroded extant sculptural details.

The continuing debate concerning the middle figure in East XI has prompted my renewed study of the composition (fig. 1). In a careful examination of the casts in Basel and Athens I have found the upper half of a bow in the top right-hand corner of the metope, which one can see mostly concealed by the shadow from the triglyph in the Basel pub. lication. ${ }^{4}$ I have also found the right foot of the central figure.

for generous access to the Skulpturhalle and for their com ments on early stages of my drawings and interpretations. My thanks are also due to R. Davidson and the anonymous AJA reviewers for their helpful criticisms and suggestions.

The following abbreviations have been used: Berger

E. Berger, Dokumentation zu den Metopen des Parthenon. Studien der Skulp. turhalle Basel (Mainz 1986).

Brommer F. Brommer, Die Metopen des Parthenon (Mainz 1967).

Praschniker C. Praschniker, Parthenonstudien (Vienna 1928).

${ }^{1}$ Praschniker. His study includes the north and east metopes of the Parthenon.

2 A. Michaelis, Der Parthenon (Leipzig 1870-1871) 143.

${ }^{3}$ The temple was converted to a Christian church during the reign of the emperor Justinian, and it is at this time that most figures in the metopes were damaged.

${ }^{4}$ Berger pl. 64. 


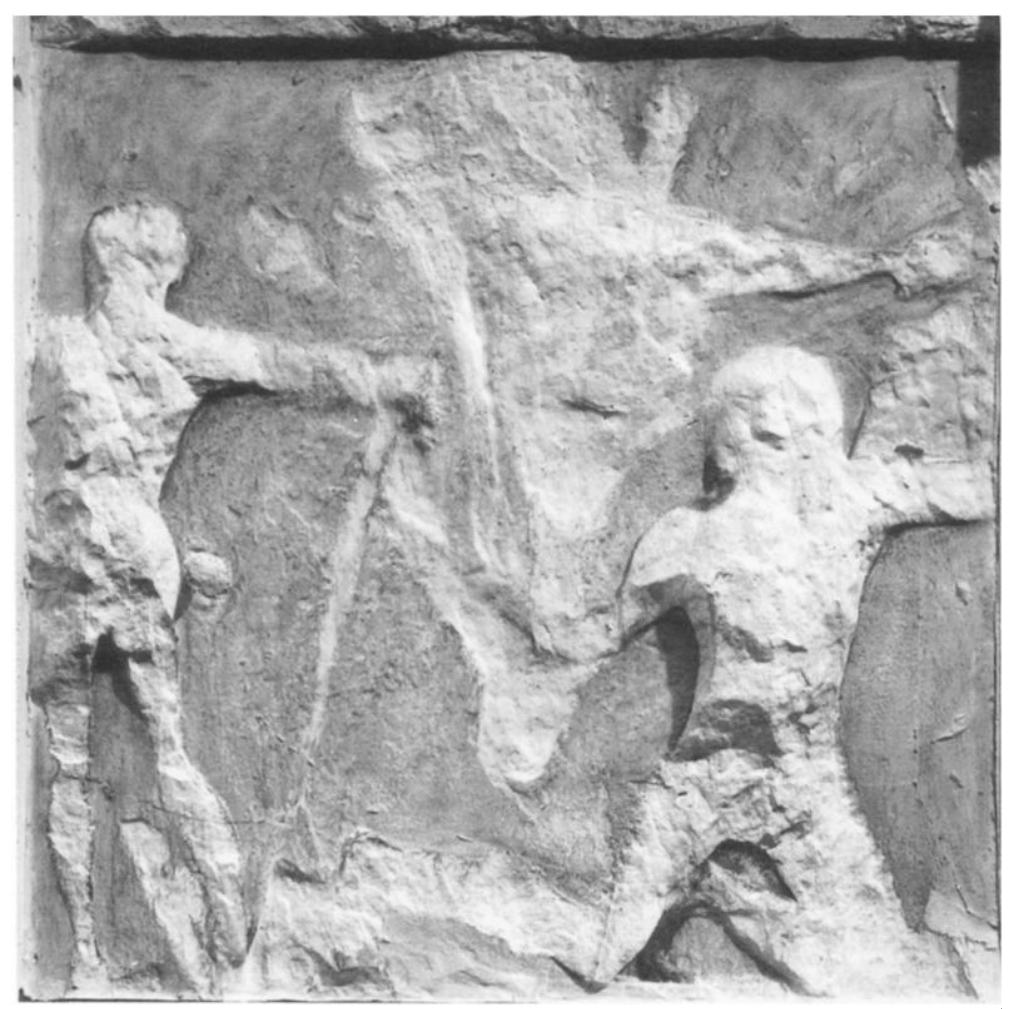

Fig. 1. Cast of metope East XI, Basel, Skulpturhalle. (Berger pl. 64, Photo D. Widmer)

\section{METHOD}

My study of Parthenon East Metope XI, the most problematic metope of the east series, has been based on plaster casts and a comparison of the Gigantomachy in the compositions from the east metopes with those on vases of the fifth century B.C. From these results and a synthesis of the drawings published by Praschniker and the photographs published by Brommer, I have developed a drawing system, using Praschniker's line drawing as the basis, that attempts to show where the carved surface is preserved with a sharp black contour and added shading to suggest volume (fig. 2). Where the contour is not extant or is at best merely suggested, light shading is used. The resulting drawing is intended to give one a greater sense of the three-dimensionality of the original composition than one perhaps sees in Praschniker's drawing of the metope composition (fig. 3). The new drawing provides an opportunity to incorporate details visible in Brommer's photographs, E. Berger's publication of the Basel casts, and my discoveries and observations from studying the casts in Basel and Athens. ${ }^{5}$

The complexity of the original composition in at least some of the east metopes is now indicated,

${ }^{5}$ See G.B. Waywell's review of Berger in Gnomon 60 (1988) 57-60. thanks to M. Korres, who found evidence for the presence of four, not two, horses pulling the chariot of Helios above Okeanos in East XIV. 6 The outermost horse would have projected beyond the metope floor, thus giving us a spectacular quadriga prominently displayed at the right end of the series. Such a discovery makes it more than likely that the other compositions were potentially as complex in the arrangement of dueling figures and chariot groups. The addition of bronze attachments, particularly weaponry, and paint for details such as hair, eyes, lips, drapery, and the possibility of red for the background plane all would have contributed to a dynamic battle between the Olympian gods and the Earth-born giants on the east facade of the Parthenon.

Most of Praschniker's identifications for the figures in the east metopes have been accepted by scholars in subsequent studies. Some of these identifications have been challenged, however, including the most badly damaged figure in metope East XI, the central figure. Unlike the majority of compositions in the east series, East XI has three figures instead of two. Only one other metope has three figures, East IV, to which we will return. Praschniker associated Herakles with the central figure in East XI, accompa-

\footnotetext{
${ }^{6}$ M. Korres, "Acropole, travaux de restauration du
} Parthénon,” BCH 115 (1991) 839. 


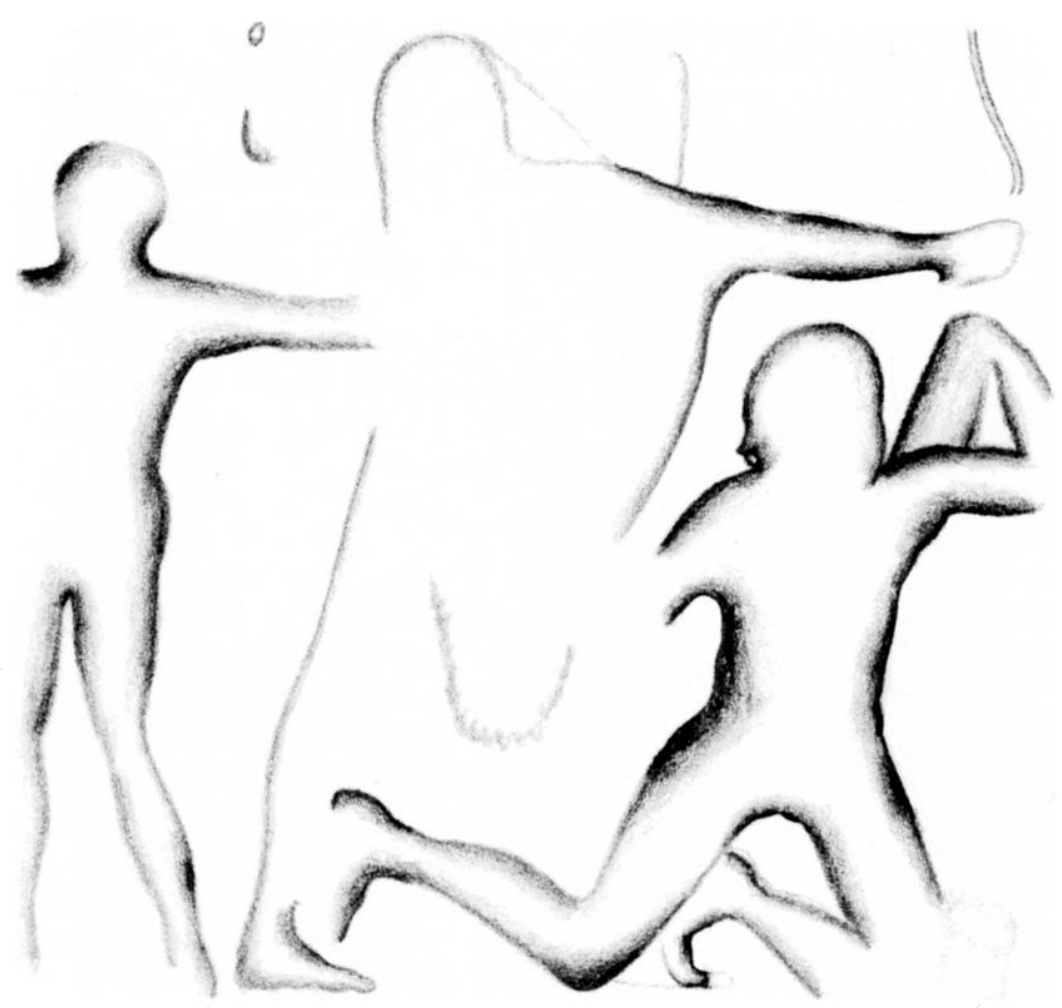

Fig. 2. Drawing of metope East XI. (K.A. Schwab)

nied by Eros at left, another archer, in the defeat of a falling giant at right. ${ }^{7}$ Brommer disagreed with Praschniker, preferring instead to see the mortal hero in East IX as the fleeing figure at left rather than a giant, while proposing Apollo as the principal figure in East XI. ${ }^{8}$ Herakles, however, never appears in a defensive posture during the Gigantomachy on vases where he is clearly recognizable. Instead, he is consistently shown as an aggressive archer fighting alongside the Olympians. Placing Herakles in East IX as the fleeing figure is most doubtful. Equally problematic is Brommer's suggestion to move Apollo, traditionally the figure at right in East IX, to East XI. The attacking figure, at right in East IX, with conspicuous emphasis given to long beautiful hair and flowing cloak, belongs to Apollo in representations of the Gigantomachy on vases. ${ }^{9}$

M. Tiverios, in 1982, proposed Ares for the central figure in East XI due to the proximity to Aphrodite in the adjacent metope East XII, and he moved Herakles to East XIII. ${ }^{10}$ Again, the problem of moving one of the gods, with well-established iconogra-

\footnotetext{
7 Praschniker 174, 216, pl. XXIV.

${ }^{8}$ Brommer 34-35, 203-204, 207-208, pls. 71-74.

${ }^{9}$ For example, a cup signed by Aristophanes and Erginos, ca. 410 B.C., Berlin 2531. Cf. CVA Berlin (3) pl. 119; ARV ${ }^{2}$ 1318-19.1; Paralipomena 478; Beazley Addenda 363.
}

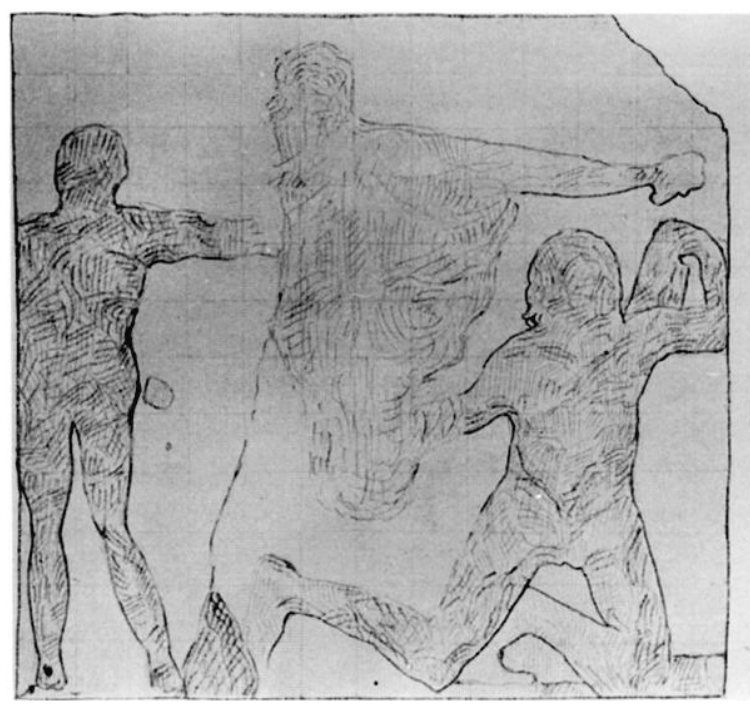

Fig. 3. Drawing of metope East XI. (Praschniker pl. 24)

phy for this battle, creates an awkward solution. Ares belongs in East III as the attacking figure at left, equipped with a large round shield and probably

$\rightarrow$ M.A. Tiverios, "Observations on the East Metopes of the Parthenon," AJA 86 (1982) 227-29. Aphrodite (XII) and Ares (III), however, can be visually linked by their position, third metope from either end. 
a spear. ${ }^{11}$ Berger, in his publication of the plaster casts in Basel, suggested either Hephaistos or Herakles for the disputed figure in East XI. ${ }^{12}$ My earlier study of these metopes, in a comparison with representations on vases, supports the identifications first proposed by Praschniker for East XI: Herakles, accompanied by Eros, defeating a giant. ${ }^{13}$ Recently, S. Woodford, in her discussion of Herakles in LIMC $\mathrm{V}$, discounts the identification of Herakles as the central figure. ${ }^{14}$

\section{HERAKLES}

In metope East XI the principal figure, Herakles, attacks to the right. Surface features to the left of his head suggest that his right arm is raised above and behind his head, a position appropriate to wield a club. His left arm is straight and extended to the right, behind and above the giant's head. ${ }^{15} \mathrm{He}$ originally held a thin curved object in his left hand, a small piece of which is preserved and restored by Praschniker as a small bow held at an oblique angle. ${ }^{16}$ The bow, however, should be placed on the vertical and drawn much larger. ${ }^{17}$ Evidence for a large bow is indicated by a raised ridge beginning at the top of the metope, arcing to the right just above his left hand (fig. 1). This ridge is unrelated to a break in the upper right corner. Nothing remains of the lower half of the bow.

Herakles would have worn a lion skin tied around his chest and hanging over his shoulders down his back, protectively covering his left arm from shoulder to elbow. The right edge of the lion skin seems

${ }^{11}$ Praschniker 194, pl. XVI; Brommer 25, 200, pls. 45-47; Berger 60, pls. 42-43. Praschniker reconstructed Ares fighting with a sword held in a thrusting position. I would suggest reconstructing the god holding a spear in his raised right hand, as he is consistently shown in representations of the battle on vases. For a brief discussion on representations of Ares in the Gigantomachy, see I. Beck, Ares in Vasenmalerei Relief und Rundplastik (Archäologische Studien 7, Frankfurt 1984) 39-43.

${ }^{12}$ Berger 66-68, pls. 64, 72.1.

${ }^{13}$ K.A. Schwab, The Parthenon Metopes and Greek Vase Painting: A Study of Comparison and Influences (Diss. New York Univ. 1988) 5-75, esp. 60-62.

${ }^{14}$ LIMC V, 173 no. 3451, s.v. Herakles (S. Woodford): Parthenon East XI-"Praschniker's identification of the figure fighting a giant beside Eros as $\mathrm{H}$. is generally now discounted: see Berger 57, 66-68."

${ }_{15}$ Praschniker 174, 216, pl. XXIV; Brommer 34-35, 203-204, 207-208, pls. 71-74; Berger (supra n. 12).

${ }_{16}^{16}$ Praschniker 216, 218, fig. 128. He restores all three figures with bows.

17 The top of the bow measures ca. $10 \mathrm{~cm}$ from the right triglyph and ca. $25 \mathrm{~cm}$ in height. to be strongly suggested by the shape of the damaged surface within this area. Although Herakles' legs are not preserved, the outline of his right foot can be detected at the lower edge when examining the cast in a raking light. The toes are pointed to the right, giving the hero a striding pose to the right, unlike Praschniker's reconstruction of the stance with a frontal pose and bent knees. The striding pose helps to explain a damaged long line or edge that should now suggest where his right leg joined the background plane. My reconstruction drawing shows these discoveries and adjustments to Praschniker's drawing (fig. 2).

When Herakles fights in the Gigantomachy on Attic vases he is always represented drawing his bow and shooting to the right. Around the time of the Parthenon he stands while drawing his bow - this position is seen on the Ferrara calyx krater attributed to the Niobid Painter, on the Basel calyx krater in the manner of the Niobid Painter, and on the unattributed volute krater in Mulgrave Castle. ${ }^{18}$ On later vases, Herakles kneels while drawing his bow, as on the fragmentary calyx krater in Ferrara in the manner of the Peleus Painter, and on the neckamphora in the Louvre attributed to the Suessula Painter. ${ }^{19}$

It is unusual for Herakles to appear in this battle wielding a club and holding out a bow as he seems to have done on the Parthenon metope. ${ }^{20}$ In representations of the Heraklean Amazonomachy, however, this pose is known as early as the volute krater by Euphronios in Arezzo. ${ }^{21}$ A decade earlier than

${ }^{18}$ Ferrara T. 313, (inv. 2891), from Spina, $A R V^{2} 602.24$ and 1661; Paralipomena 395; Beazley Addenda ${ }^{2}$ 266-67; CVA Ferrara (1) pls. 17-18. Basel, Antikenmuseum und Sammlung Ludwig, $A R V^{2}$ 609.7bis (cf. p. 1661); Paralipomena 396; Beazley Addenda2 268; F. Brommer, Hephaistos (Mainz 1978) pl. 18. Whitby, Mulgrave Castle, Marquess of Normanby, Paralipomena 442.

${ }^{19}$ Ferrara, T. 300 (inv. 2892), from Spina, $A R V^{2} 1041.6$ and 1679; Paralipomena 443; Beazley Addenda ${ }^{2}$ 319; CVA Ferrara (1) pl. 19. Paris, Louvre S 1677, $A R V^{2} 1344.1$ and 1691; Paralipomena 482; Beazley Addenda ${ }^{2}$ 367; FR pls. 96-97.

${ }^{20}$ The earliest-preserved representation of Herakles wielding a club in the Gigantomachy on vases is a midfourth century Apulian volute krater from Ceglie, Bari 4399, attributed to the Milan Orpheus Group, close in style to the Lycurgus Painter and the Painter of Boston 76.65, cf. RVAp I, 421, no. 44; A. von Salis, "Die Gigantomachie am Schilde der Athena Parthenos," JdI 55 (1940) 96, figs. 6-7.

${ }^{21}$ Arezzo 1465, $A R V^{2}$ 15.6; Paralipomena 322; Beazley Addenda ${ }^{2}$ 152. See D. von Bothmer, Amazons in Greek Art (Oxford 1957) pl. 69.3a; and Capolavori di Euphronios: Un pion. iere della ceramografia attica (Milan 1990) 38, 100-107, no. 13. 
the Parthenon is a stamnos attributed to the Altamura Painter in St. Petersburg, on which the combination is used again in a scene with Herakles fighting Amazons. ${ }^{22}$ The St. Petersburg stamnos is helpful as well in providing a parallel for the stance of the hero. These examples from the Amazonomachy assist in reconstructing the general pose striding to right and choice of attributes for the hero: club, and bow and arrows. ${ }^{23}$

\section{GIANT}

Praschniker restores the kneeling giant reaching for an arrow from his quiver, but the straight oblique cutting on the metope just above the base of the giant's neck could with more justification be taken for an arrow stuck in his back, similar to the "Kapaneus" motif. ${ }^{24}$ The giant would then be reaching for the arrow with his left hand, trying to pull it out. Normally an archer is shown reaching for an arrow in the quiver with the right hand. Praschniker equipped this giant with bow and arrows, perhaps to give the three figures in the composition the same weaponry, yet such a reconstruction is an unconvincing action for the giant.

Equally important are the giant's arching back and general posture, both strongly suggesting that he is twisting to pull away from the source of the assault -

${ }^{22}$ St. Petersburg 807, $A R V^{2}$ 593.42; Paralipomena 513; Beazley Addenda 265.

23 The bow and arrows were a gift from a renowned archer, Apollo; the club Herakles made himself in Nemea, cf. Apollod. Bibl. 2.4.11.

24 The motif of someone being wounded in the back can be subdivided into two groups: reaching with one hand to pull out the weapon, or with both hands. For some examples on vases with one hand see: the giant Porphyrion on a fragmentary calyx krater in the manner of the Peleus Painter in Ferrara (supra n. 19), a Greek in an Amazonomachy on the reverse of the volute krater attributed to the Painter of the Woolly Satyrs in New York (New York 07.286.84: $A R V^{2}$ 613.1; G.M.A. Richter and L. Hall, Redfigured Athenian Vases in the Metropolitan Museum of Art [New Haven 1936] pls. 97-98; Bothmer [supra n. 21] 167-69), a satyr on a column krater by the Orpheus Painter in Athens (Athens, NM 1167: $A R V^{2}$ 1104.6); with two hands: a kneeling Greek in an Amazonomachy on an unattributed pelike from Agrigento, now lost (Bothmer [supra n. 21] 185, pl. 81.1), and a suitor of Penelope on a skyphos in Berlin by the Penelope Painter (Berlin 2588: ARV 1300.1 ; G. von Lücken, Greek Vase-Paintings [The Hague 1923] pls. 16-17). In sculpture the motif is well known from the so-called Kapaneus figure on the Parthenos shield (one hand), finished shortly after the metopes, as well as the Terme Niobid (two hands). A centaur reaches toward his wounded back, possibly with both hands, in Parthenon metope South XXVII; and twice on the Bassai frieze: slab 528 (wounded
Eros and Herakles - while extracting the arrow stuck in his back. ${ }^{25}$ With his right hand he tries vainly to push Herakles away. G. Despinis has identified a head fragment that may belong to the giant in this metope. ${ }^{26}$ It preserves thick unruly hair and a large right eye. This fragment would suit a reconstruction showing the giant's head turned to the right looking away from Herakles and Eros as he struggles to remove the arrow.

\section{EROS}

Perhaps the figure to the left of Herakles shot the arrow. This figure is shown in frontal view with his head and shoulders in three-quarter view to the right. His arms are extended to the right, the right overlapping the left, a stance appropriate to shooting an arrow. The pose of this figure has no exact parallel in contemporary and later Gigantomachies. The figure cannot be Iolaos, the companion of Herakles in his Labors, for he does not participate in the Gigantomachy.

The earliest-preserved Eros shooting an arrow is on a lekythos attributed to the Brygos Painter, ca. 480 , in Fort Worth, where he appears by himself. ${ }^{27}$ The young god's target is omitted from this repre sentation, leaving the suggestion of a victim to the viewer's imagination. Praschniker was the first to iden.

back not visible), slab 529 (back is visible). For the so-called Kapaneus figure on the Parthenos shield, $\rightarrow$ E.B. Harrison, "Motifs of the City-Siege," AJA 85 (1981) 300- $\rightarrow$ A.D. Fraser, "The "Capaneus' Reliefs of the Villa Albani and the Art Institute of Chicago," AJA 43 (1939) 447-57. For the Terme Niobid (inv. no. 72274), see R. Lullies, Griechische Plastik (Munich 1979) pls. 166-67. A centaur in the west frieze of the so-called Theseum, whose arms are no longer preserved, may have been extracting a weapon such as an arrow or spear from his back; see S. von Bockelberg, AntP 18 (1979) pl. 45, fig. 17. For slabs 528 and 529 of the Bassai frieze, see B. Madigan, The Temple of Apollo Bassitas II: The Sculpture (Princeton 1992) pls. 44-45.

${ }^{25}$ The giant's arching back is best seen when examining the cast first-hand. It is less visible in the photograph, and it proved difficult to convey in my drawing. This is the same wound the Amazon's victim received on the New York volute krater attributed to the Painter of the Woolly Satyrs (supra n. 24), here clearly portrayed in backview. Another example of this motif is on the skyphos to the Penelope Painter in Berlin (supra n. 24), where Odysseus shoots ar. rows on one side of the skyphos at the suitors who are shown on the other side. Odysseus has already shot one arrow and is drawing his bow with another. The victim is strug. gling with both hands to reach the arrow stuck in his back.

${ }^{26}$ G. Despinis, Parthenoneia (Athens 1982) 2 believes that the fragment of a male head probably belongs to this giant.

${ }^{27}$ Fort Worth AP 84.16. See LIMC III, 878 no. 332, s.v. Eros (A. Hermary). 


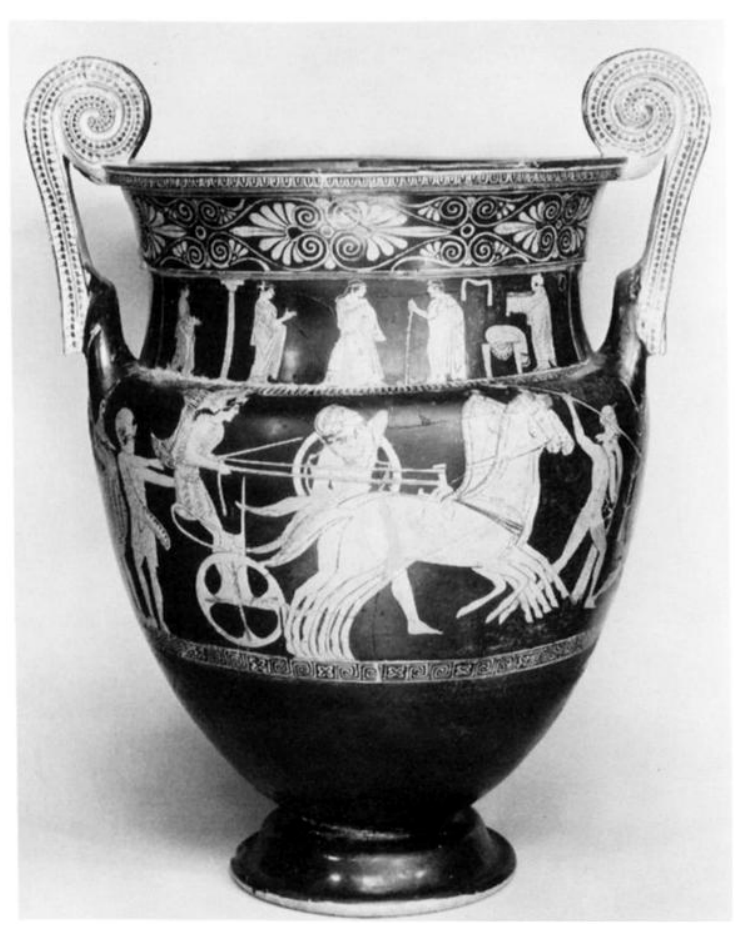

Fig. 4. Attic red-figure volute krater. Reverse, Amazonomachy. New York, Metropolitan Museum of Art, Rogers Fund, 1907 (07.286.84). (Courtesy Museum)

tify the figure as Eros, who participates in the Gigantomachy for the first time on the Parthenon. ${ }^{28}$ His earliest-preserved appearance as archer in representations of the Gigantomachy in vase painting is on the reverse of the Suessula Painter's neckamphora, ca. 400 , in the Louvre, where he can be seen perched as a diminutive figure, on the shoulder of a chariot horse driven by Aphrodite, a unique position. ${ }^{29}$ The Suessula Painter seems to have been influenced by the god's introduction into the battle on the metope.

In literature the earliest-preserved reference to Eros shooting arrows, according to Shefton, is in Euripides' Medea (431 B.C.) lines 530-31. ${ }^{30}$ Several

${ }^{28}$ F. Studniczka, NJbb 5 (1929) 650, discusses the connection between Eros and Herakles in cults at gymnasia; see also Preller-Robert I, 504, s.v. Eros (Robert). Praschniker 215-16 and Brommer 203-204 also identify the figure as Eros. His wings would have been added in paint, whereas the wings of Nike, in East IV, are carved in low relief. See also R. Vollkommer, Herakles in the Art of Classical Greece (Oxford 1988) 53 no. 395, a fourth-century metal vase (Malibu 79.A.E.119) with Herakles carrying Eros on his left arm; 82 for his discussion of Herakles as a humanized hero in the fifth century.

${ }^{29}$ See B. Shefton in P.E. Arias and M. Hirmer, A History of 1,000 Years of Greek Vase Painting (New York 1962) 381.

${ }^{30}$ Shefton (supra n. 29); trans. A.S. Way (LCL).

${ }^{31}$ Eur. Hipp. 37-38, 530-32, 1301-1303, 1417-22, trans.

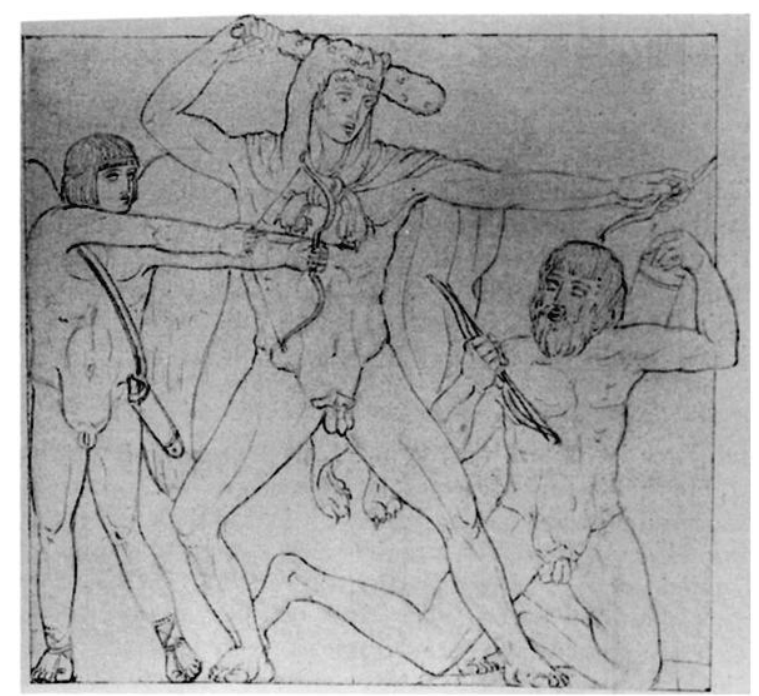

Fig. 5. Reconstruction drawing of metope East XI. (Praschniker fig. 128)

other literary examples by Euripides convey the use of arrows by both Eros and Aphrodite. ${ }^{31}$ An early fifth-century reference by Pindar refers to Aphrodite's use of these arrows and their power, a role that will be given to Eros. ${ }^{32}$

In East XI Eros has already shot his arrow. The best comparison for understanding the relaxed position of his legs is on the reverse of a volute krater in New York attributed to the Painter of the Woolly Satyrs, ca. 440 (fig. 4). An Amazon archer at left has already shot her arrow; a young Greek at right has been struck in the back. The right hand of the Amazon is empty having just released the arrow that has now found its target. This action best explains the pose of Eros in East XI whose target is the giant fallen to his knees, not the fleeing giant at far right in East XII where Aphrodite clearly has the advantage; Eros's action stays within the metope. ${ }^{33}$ This goddess has no need of assistance in the Parthenon Gigantomachy nor on the later Pergamon Altar. The

D. Greene, The Complete Greek Tragedies: Euripides I (New York 1942); Eur. Tro. 255, trans. R. Lattimore, The Complete Greek Tragedies: Euripides II (Chicago 1958); Eur. IA 546-53, trans. A.S. Way (LCL).

32 Pind. Pyth. 4.214-15, trans. J. Sandys (LCL). I am indebted to Peter Bing for this reference as well as those mentioned supra n. 31 .

${ }_{33}$ B.S. Ridgway, Fifth Century Styles in Greek Sculpture (Princeton 1981) 21 and 23, refers to Eros shooting across the triglyph to assist Aphrodite. LIMC IV, 206, s.v. Gigantes (F. Vian) also describes Eros shooting at Aphrodite's opponent in East XII. The fleeing giant in East XII does not react as if he has been struck by an arrow, although Eros has already released his weapon. 


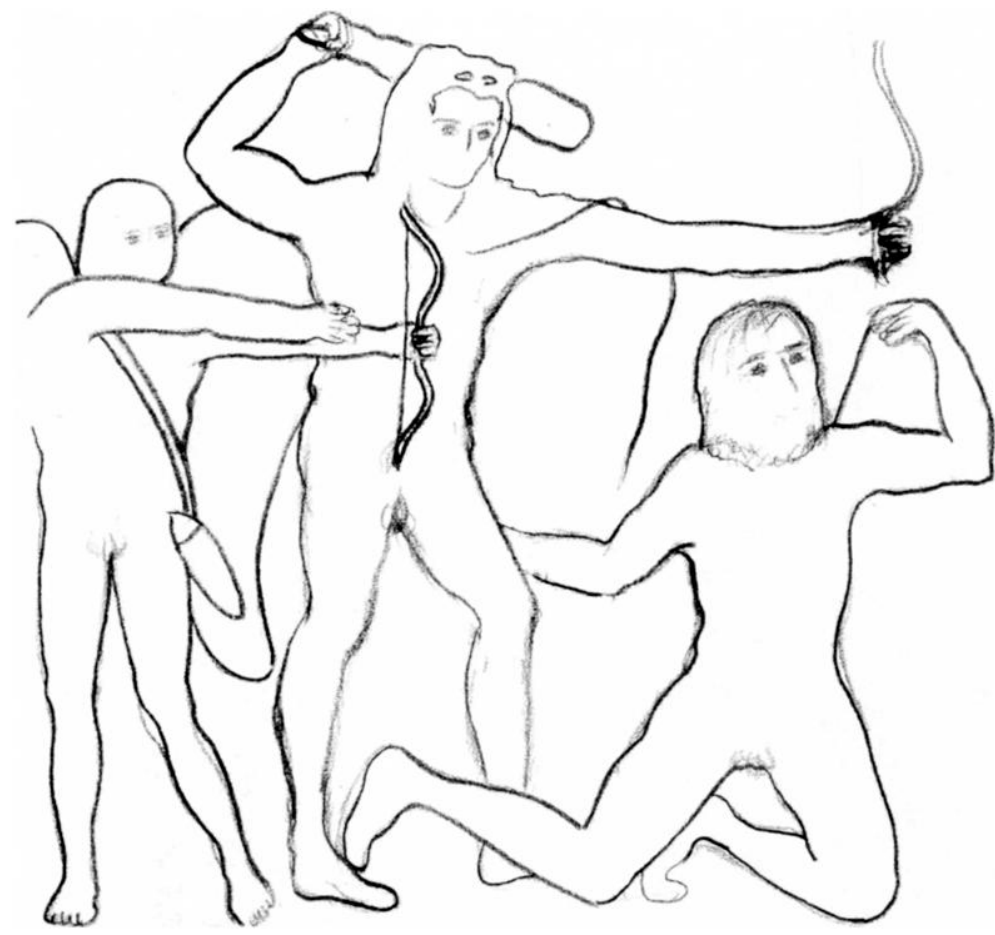

Fig. 6. Reconstruction drawing of metope East XI. (K.A. Schwab)

proximity of Eros to his mother in the adjacent metope East XII and his cult associated with Herakles at Thespiae, combined with his renowned archery prowess, best support his presence here in East XI. ${ }^{34}$

\section{INTERPRETATION}

The inclusion of Herakles, and his active participation in the battle against the giants, is essential for an Olympian victory. ${ }^{35}$ After Zeus had commanded Helios to stop, Athena traveled in darkness to find the mortal hero Herakles who, according to an oracle, would bring the gods victory. Herakles, in pose, attributes, and action, is the only possibility for the central figure in East XI. No other figure in the east metopes is a viable candidate for the hero.

Herakles is usually shown fighting near Zeus and Athena in representations of the Gigantomachy on vases. His participation with Zeus and Athena is essential for the battle, and it forms the basis for any representation of the conflict. This arrangement can be seen on the obverse of the Suessula Painter's amphora in the Louvre where Herakles and Athena fight

\footnotetext{
${ }^{34}$ Studniczka (supra n. 28).

${ }^{35}$ Apollod. Bibl. 1.6.1-3 for the fullest account. Herakles had destroyed Cos when "he came through Athena's agency to Phlegra, and sided with the gods in their victorious war on the giants," cf. Bibl. 2.7.1. Earlier sources include Homer (Od. 7.59), Hesiod (Theog. 185), and Pindar (Nem. 1.66-69). See LIMC IV, 191-96, s.v. Gigantes (F. Vian).
}

back to back while Zeus attacks from a chariot behind them.

Praschniker reconstructed each figure equipped with a small bow, and with the giant turning toward Herakles (fig. 5). In my reconstruction drawing the figures have been adjusted to reflect the discovery of Herakles' large bow held in a vertical position, and the position of his right foot and striding pose to the right (fig. 6). The giant is shown reaching for an arrow stuck in his arched back or for some other object in that area. His face is now turned to our right, away from Herakles.

In East XI Herakles has the privilege of inflicting the final blow with his club, rather than shooting his arrows after the gods had wounded their adversar. ies. The hero does not relinquish his bow, however, for he holds it in his left hand. Thus, for the first time Herakles is joined by someone else renowned for his accuracy as an archer. This introduces a new force into the battle, that of Eros who uses his potent weapons to fight the Earth-born giants. ${ }^{36}$

While most of the east metopes have either a duel

\footnotetext{
${ }^{36}$ Gods and hero renowned for their deadly aim with bow and arrow appear exclusively in the right half of the east metope series: East IX Apollo, East X Artemis, East XI Eros and Herakles. Herakles' arrows will also play a crucial role in defeating the Trojans; the Sack of Troy is represented in the north metopes.
} 


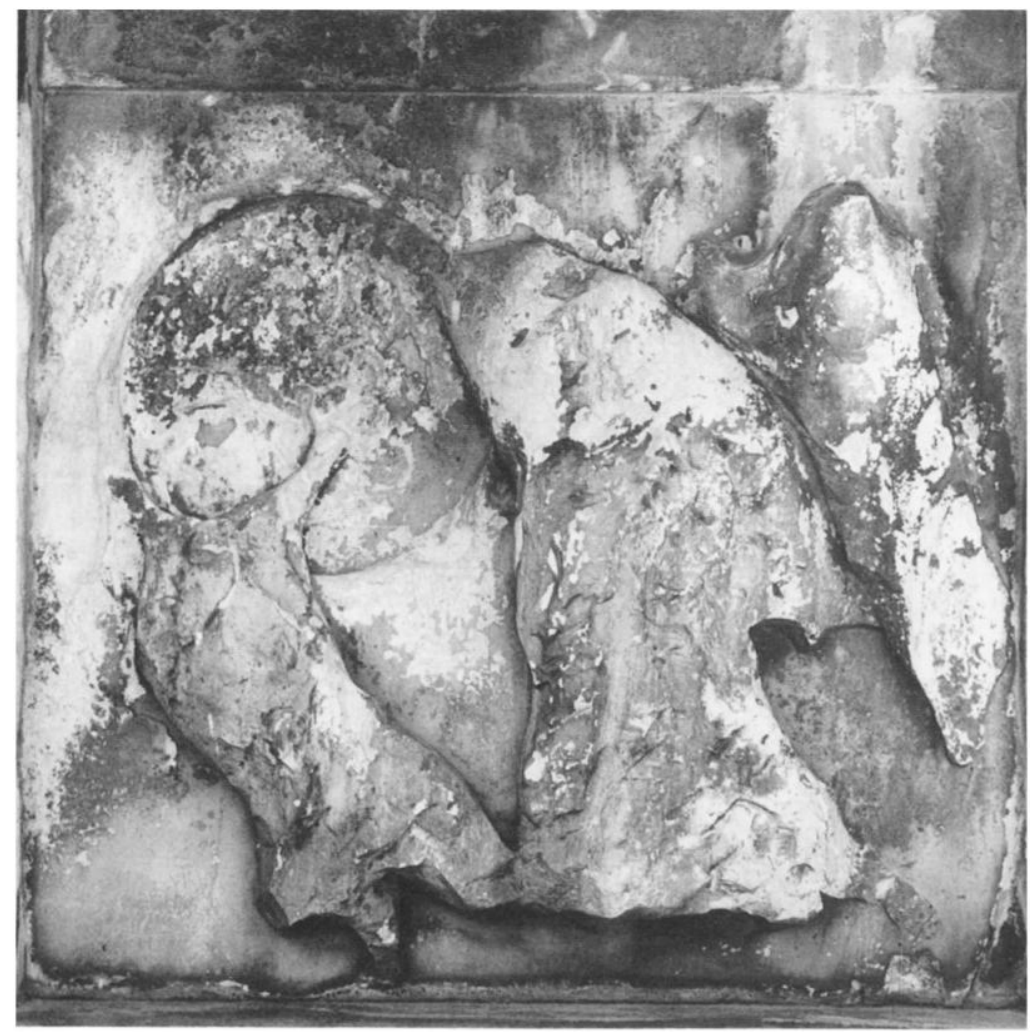

Fig. 7. Metope East IV. (Brommer pl. 49, Deutsches Archäologisches Institut, Athens, Akr. 2049)

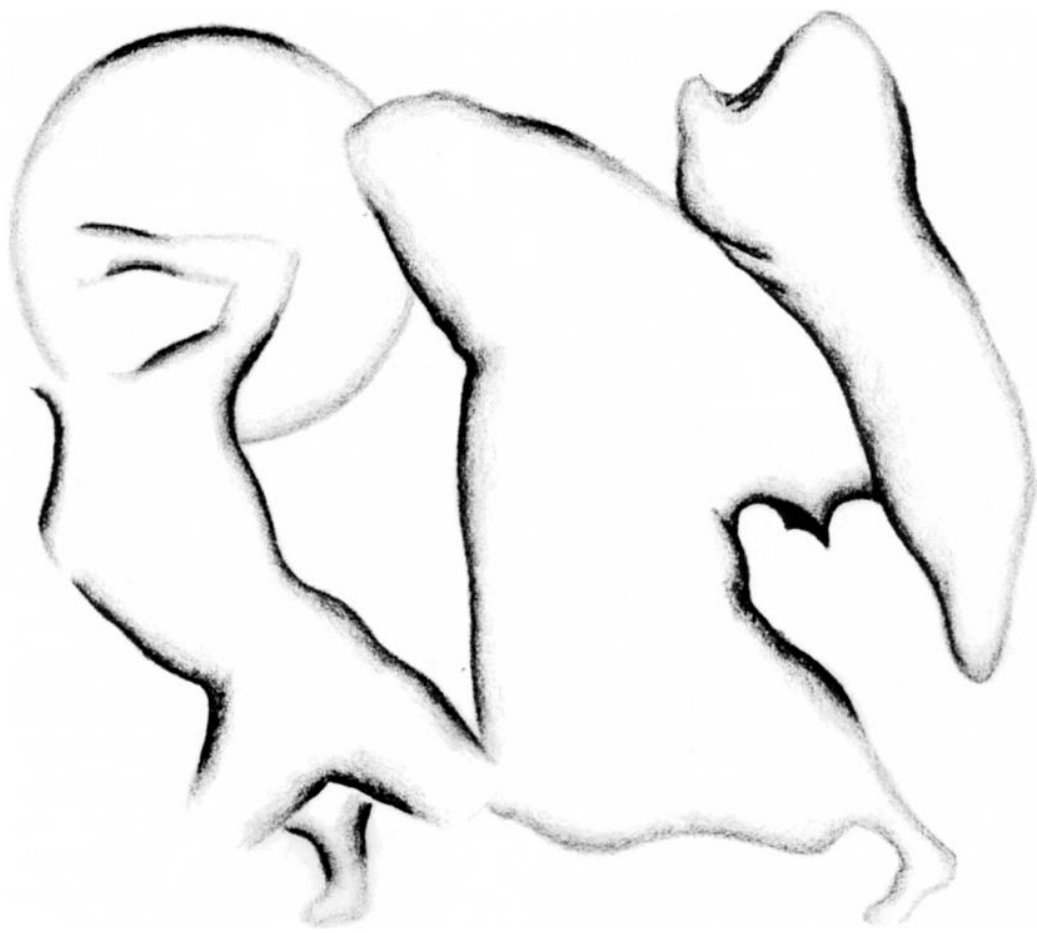

Fig. 8. Drawing of metope East IV. (K.A. Schwab) 


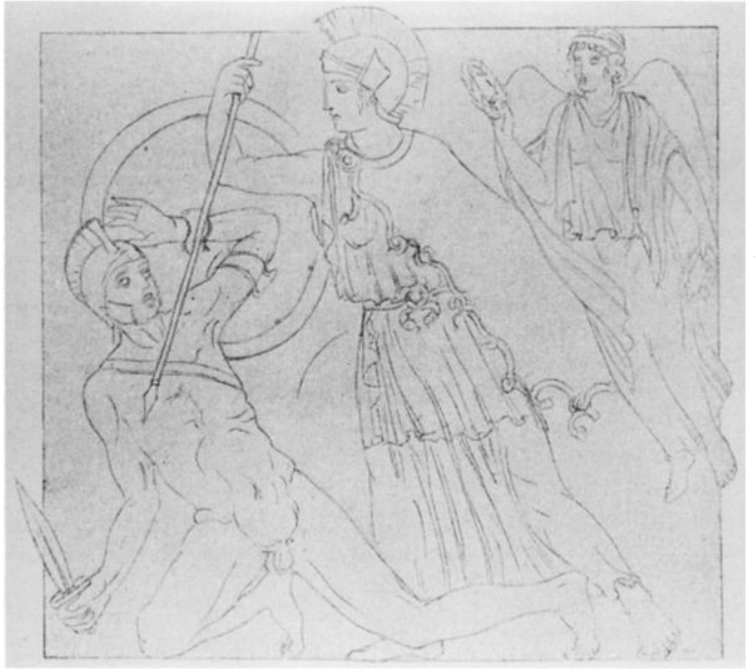

Fig. 9. Reconstruction drawing of metope East IV. (Praschniker fig. 121)

or a chariot group, only one other metope has a threefigure composition: East IV with Athena fighting to the left while being crowned victorious by Nike hovering at right. ${ }^{37}$ Brommer's photograph shows the general condition of the metope (fig. 7), while my drawing (fig. 8) and Praschniker's reconstruction drawing (fig. 9) give a sense of the composition. Nike, like Eros, is introduced in the battle here on the Parthenon. Special significance seems to have been given to these two metopes, the only compositions with three figures, both placed fourth in from the ends of this series. This symmetrical arrangement high-

${ }^{37}$ Duels: East I, II, III, VI, VIII, IX, XII, XIII; chariot groups: East V, VII, X, XIV. The rhythm of violent duels is countered with quieter interludes offered by the chariot groups. East IV: Praschniker 154-55, 196-97, pl. XVII; Brommer 26-27, 200-201, pls. 48-49; Berger 60-61, pls. 44-46, 47.1.

${ }^{38}$ East VIII Zeus: Praschniker 166-67, 204, pl. XXI; Brommer 30, 205, pls. 60-63; Berger 64, pls. 56-57. Zeus is to the right of center because of the even number of metopes. Together with his consort Hera in East VII, they form the center of the battle. Vollkommer (supra n. 28) 90 notes the significance of Herakles as a symbol of victory.

${ }^{39}$ East I-II: Hermes and Dionysos (Birth of Dionysos); East III-IV: Ares and Athena/Nike (war, victory in battle); East V-VI: Amphitrite and Poseidon (consorts); East VII-VIII: Hera and Zeus (consorts); East IX-X: Apollo and Artemis (brother-sister); East XI-XII: Herakles/Eros and Aphrodite (archers, mother/son); East XIII-XIV: Hephaistos and Helios (Helios assists Hephaistos twice). Aphrodite will give Hebe to Herakles when he achieves immortality, cf. Pind. Nem. 1.67-72 and Isthm. 4.59-61. See also an Attic red-figure hydria, ca. 400-350 B.C., near the Group of Lon- lights Herakles' role in the Gigantomachy and the special association he enjoyed with Athena, who brings glory to the hero and to the city of Athens. Together with Zeus identified in East VIII we have the triad essential to the battle in overcoming the giants' challenge to the preeminence of the Olympian gods (fig. 10). ${ }^{38}$

The prominence given to the triad is seen in the east facade when examining the correspondences to architectural features. Each intercolumniation marks off a pair of metopes, and these pairs reflect well-known relationships. ${ }^{39}$ These interconnections describe relationships that form the strength of unity the Olympians required when opposing the formidable power of the giants.

An examination of the ground plan reveals an alignment of the metopes with the cella; their placement was intentional and the relationships between other Olympians become more obvious as well when associated with the architecture. Both East IV and XI correspond to the cella side aisles, while East V-X are associated with the cella interior. ${ }^{40}$ East III and XII (Ares and Aphrodite) are aligned with the cella walls, while the outermost two on either end belong to the colonnade. ${ }^{41}$

The identification of Herakles as the central figure in East XI, first proposed by Praschniker, is correct. His presence in the east metopes is assured and conspicuous, for he is given a prominent role in the battle, which is known from the literary evidence and in representations on vases. He is linked with Athena, the patron deity of Athens, who is celebrated

don E 230, with Herakles next to a seated Hebe, with Eros at her knees, and perhaps Aphrodite moving to left; cf. LIMC V, 164, no. 3342, s.v. Herakles (J. Boardman et al.); $A R V^{2}$ 1481; and CVA British Museum (6) 9 and pl. 98.5 (E 244).

${ }^{40}$ East V: Amphitrite; VI: Poseidon; VII: Hera; VIII: Zeus; IX: Apollo; X: Artemis.

${ }^{41}$ East I: Hermes; II: Dionysos. They sit together in the left half of the assembly of gods in the Parthenon east frieze, slab East IV, figs. 24-25. The Phiale Painter's well-known calyx krater in the Vatican shows Hermes carrying the infant Dionysos to the nymphs of Nysa (Vatican 16586: $A R V^{2}$ 1017.54 and 1678; Paralipomena 440; Beazley Addenda ${ }^{2}$ 315; see J.H. Oakley, The Phiale Painter [Kerameus 8, Mainz 1990] 75-76, pl. 38). East XIII: Hephaistos; XIV: Helios. Helios assisted Hephaistos twice: when he was weary at the end of the battle against the giants, Helios carried him in his chariot (cf. Ap. Rhod. Argon. 3.232-34), and he alerted Hephaistos of his wife's affair with Ares, cf. Hom. Od. 8.270). In both pairs we have examples of assisting roles performed by Hermes for Dionysos and Helios for Hephaistos. 


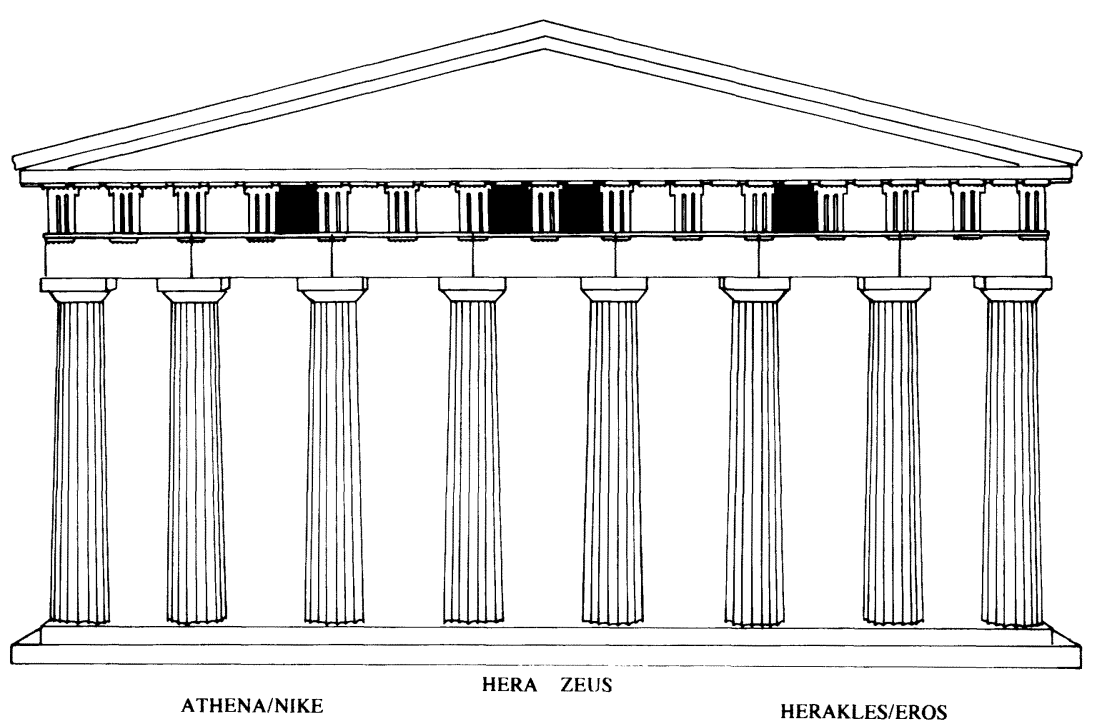

Fig. 10. Parthenon east facade with triad in darkened metopes. (Adapted from E. Berger, AntK 23 [1980] pl. 23.1)

throughout the sculptural program of the Parthenon. ${ }^{2}$ Herakles' association with Athena is well attested both in the Labors and in his Introduction to Mt. Olympos. The introduction of two new forcesEros and Nike-enhance the two compositions and give added advantage to the Olympians. Herakles, by his mere presence, symbolizes victory over the giants as the oracle had predicted. Nike, as the per. sonification of victory, crowns Athena. A magnificent four-horse chariot pulling Helios into the sky to start a new day in East XIV further emphasizes that, while the battle is fully engaged, the outcome is assured with the participation of the mortal hero Herakles guaranteeing an Olympian victory. The giants, already outnumbered, have little chance against such potent symbols of victory.

\author{
FINE ARTS DEPARTMENT \\ FAIRFIELD UNIVERSITY \\ FAIRFIELD, CONNECTICUT O6430-5195 \\ KASCHWAB@FAIR1.FAIRFIELD.EDU
}

\footnotetext{
42 Other representations of Athena in the Parthenon sculptural program include Athena Parthenos and her shield: possibly in the painted Gigantomachy on the in. terior; pediments: fig. $L$ of the west pediment, and in the missing central group of the east pediment; frieze: slab V/36 of the east frieze, and possibly in the Gigantomachy
}

woven into the peplos for the Panathenaic celebration, slab V/34-35; metopes: North XXV as the statue, North XXVII in the Theft of the Palladion, North I possibly the charioteer, and she would also have appeared as a statue in the Rape of Cassandra by Ajax, no longer extant. 